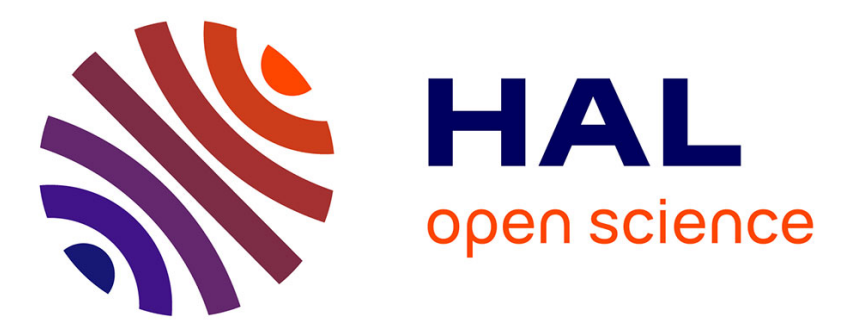

\title{
Evolution of soil carbon with various cropping sequences on the rolling pampas. Determination of carbon origin using variations in natural $13 \mathrm{C}$ abundance
}

\author{
Adrian Andriulo, Jérôme Guérif, Bruno Mary
}

\section{- To cite this version:}

Adrian Andriulo, Jérôme Guérif, Bruno Mary. Evolution of soil carbon with various cropping sequences on the rolling pampas. Determination of carbon origin using variations in natural $13 \mathrm{C}$ abundance. Agronomie, 1999, 19 (5), pp.349-364. hal-00885936

\section{HAL Id: hal-00885936 https://hal.science/hal-00885936}

Submitted on 1 Jan 1999

HAL is a multi-disciplinary open access archive for the deposit and dissemination of scientific research documents, whether they are published or not. The documents may come from teaching and research institutions in France or abroad, or from public or private research centers.
L'archive ouverte pluridisciplinaire HAL, est destinée au dépôt et à la diffusion de documents scientifiques de niveau recherche, publiés ou non, émanant des établissements d'enseignement et de recherche français ou étrangers, des laboratoires publics ou privés. 


\title{
Evolution of soil carbon with various cropping sequences on the rolling pampas. Determination of carbon origin using variations in natural ${ }^{13} \mathrm{C}$ abundance
}

\author{
Adrian Andriulo ${ }^{\mathrm{a}^{*}}$, Jérôme Guérif ${ }^{\mathrm{b}}$, Bruno Mary ${ }^{\mathrm{b}}$ \\ ${ }^{a}$ INTA, Estación Experimental de Pergamino, CC 31(2700), Pergamino, Argentina \\ ${ }^{b}$ Inra, unité d'agronomie de Laon-Péronne, rue Fernand Christ, 02007 Laon cedex, France
}

(Received 12 November 1998, accepted 9 March 1999)

\begin{abstract}
The evolution of organic matter is studied in the soils of the humid central Argentinean pampas, which are extensively cultivated, without the use of fertilisers. The organic carbon contents of the soils were recorded on two sites for 13 years. At Oliveros, five rotations were compared after 60 years of cropping: wheat monoculture (Triticum aestivum L.), maize monoculture (Zea mays L.), wheat/soybean (Glycine max L.), wheat/soybean-maize and wheat/soybean-sunflower (Helianthus annuus L.). At Pergamino, a soybean monoculture followed directly after ploughing in the original pasture. Measurements of the variation in the ${ }^{13} \mathrm{C}$ isotopic composition were made to determine the proportions of 'young' C (derived from crops) and 'old' C (present at the start of the experiments) in the total reserve of organic C. At Oliveros, the soil $\mathrm{C}$ contents fell markedly during the first 5 years of the experiment (a loss of about $9 \%$ ) and then seemed to have stabilised for all the rotations. The amount of young $\mathrm{C}$ formed by the end of 13 years varied from 3.9 to $9.9 \mathrm{Mg} \mathrm{ha}^{-1}$, i.e. $10-17 \%$ of the returned carbon. At Pergamino, ploughing the pasture caused a large fall in the organic carbon $(28 \%)$ during the 13 years of soybean monoculture. The amount of old $\mathrm{C}$ fell rapidly, its renewal time being 24 years. (C Inra/Elsevier, Paris.)
\end{abstract}

soil carbon / ${ }^{13} \mathrm{C}$ abundance / rolling pampas / cropping / rotations

Résumé - Évolution des stocks de carbone des sols de la pampa argentine. Détermination de l'origine du carbone en utilisant les variations d'abondance naturelle ${ }^{13} \mathrm{C}$. L'évolution des matières organiques est étudiée dans les sols de la Pampa centrale humide argentine, cultivés de façon extensive, sans apport d'engrais. Les stocks de carbone organique des sols ont été suivis sur deux sites pendant 13 années. A Oliveros, cinq rotations sont comparées après 60 ans de mise en culture : monoculture de blé (Triticum aestivum L.), monoculture de maïs (Zea mais L.), rotation blé/soja (Glycine

Communicated by Gérard Guyot (Avignon, France)

* Correspondence and reprints

andriulo@inta.gov.ar 
max L.), blé/soja-maïs ou blé/soja-tournesol (Heliantus annuus L.). À Pergamino, une monoculture de soja a directement suivi le retournement de la prairie originelle. Des mesures de variation de la composition isotopique ${ }^{13} \mathrm{C}$ ont été effectuées afin de déterminer la part respective du $\mathrm{C}$ « jeune » (provenant des cultures) et du $\mathrm{C}$ « ancien » (présent au départ des essais) dans le stock total de $\mathrm{C}$ organique. À Oliveros, les stocks de $\mathrm{C}$ du sol ont nettement diminué pendant les cinq premières années de l'essai (perte de $9 \%$ environ) puis semblent s'être stabilisés, quelle que soit la rotation. La quantité de $\mathrm{C}$ jeune formé au bout de 13 ans varie de 3,9 à $9,9 \mathrm{mg} \mathrm{ha}^{-1}$, ce qui représente 10 à $17 \%$ du $\mathrm{C}$ restitué. Á Pergamino, le retournement de la prairie a provoqué une forte chute du carbone organique (28\%) au cours des 13 années de monoculture de soja. Le stock de $\mathrm{C}$ ancien a diminué rapidement, son temps de renouvellement étant de 24 ans. (C Inra/Elsevier, Paris.)

carbone du sol / abondance de ${ }^{13} \mathrm{C}$ / pampa ondulée / mise en culture / rotations.

\section{Introduction}

The soil carbon reserve is an essential indicator for assessing the sustainability of cropping systems and their effect on the environment [48]. Loss of organic matter usually leads to a reduction in certain components of soil fertility [34, 38]. Its evolution can be measured precisely in long-term experiments.

The soil carbon reserves and their evolution depend on climatic conditions, on the nature and amount of residues incorporated and on cultural practices. Variations in the quantity of soil organic matter (SOM) are less pronounced in temperate than in tropical climates $[12,44]$. In a given soil/climatic system, the variation in SOM content is strongly correlated with the amount of residues returned to the soil $[12,25,44]$. The total amount of $\mathrm{C}$ inputs to the soil (crop residues and rhizodeposits) depends on the species grown, the cropping system and its productivity. Thus, the increase in crop production resulting from the inclusion of legumes in the rotation leads to an increase in SOM [13, 37]. Nevertheless, several studies have shown that several years of straw burning had no effect on the soil carbon reserve [15, 43]. Several authors have suggested that root systems, as compared to the aerial parts of the residues, contribute disproportionally to the maintenance of the SOM reserve [14]. Numerous studies, cited by Heal et al. [27] show that the humification rate of carbon from residues incorporated into the soil depends on the plant species and in particular on their biochemical composition. Thus, Hendrix et al. [28] observed that clover residues caused a greater loss of carbon than that observed for grasses grown with applied nitrogen. In this study, the nature of the residues had more effect than the quantity of residues applied on the loss of carbon owing to microbial respiration. In tropical perennial legume/tropical grass rotations, the legume residues rich in lignin and polyphenols allow the SOM content to increase [46].

Frequent ploughing and summer fallows contribute to the fall of the SOM reserve: on the one hand they increase the speed of decomposition of the residues, while on the other they favour the processes of erosion [15]. Soil tillage techniques, depending on their depth and degree of inversion, modify the distribution of organic matter and harvest residues in the profile. Hence, they influence the kinetics of the evolution of the organic matter; it seems that the greater the dilution, the quicker the decomposition [25]. Further possible effects of tillage are related to enhancing soil aeration and activation of the microbial biomass.

Among the methods for evaluating organic matter reserves, the method of isotopic tracing of natural ${ }^{13} \mathrm{C}$ has proved to be particularly suitable for identifying the origin of the carbon. This method has already been used successfully to quantify the contribution from different crops to the SOM dynamics [3, 16, 22, 24]. It has mostly been applied to cropping systems comprised exclusively of $\mathrm{C} 3$ plants $\left(\delta^{13} \mathrm{C} \approx-26 \%\right.$ ) into which $\mathrm{C} 4$ plants have been introduced $\left(\delta^{13} \mathrm{C} \approx-12 \%\right.$ o). It can also be applied to characterise the evolution of SOM reserves after ploughing in an old grass pasture consisting mainly of $\mathrm{C} 4$ plants and the establish- 
ment of C3 crops, as was carried out by Balesdent et al. [4] in a long-term experiment at Sanborn in the USA.

In the rolling pampas, the original grassland is made up of a mixed population of $\mathrm{C} 3$ and $\mathrm{C} 4$ plants; the soil therefore exhibits an intermediate isotopic composition: $\delta^{13} \mathrm{C} \approx-18$ to $-21 \%$, according to the latitude. This initial state provides the advantage, in theory, of being able to follow both the decline of $\delta^{13} \mathrm{C}$ in the soil following the introduction of $\mathrm{C} 3$ plants and its enrichment after the introduction of $\mathrm{C} 4$ plants.

This paper aims at testing the applicability of the ${ }^{13} \mathrm{C}$ tracing method in the Argentinean conditions, where the original grassland composed of mixed $\mathrm{C} 3 / \mathrm{C} 4$ species is cultivated with $\mathrm{C} 3$ or $\mathrm{C} 4$ crops. We will try to use it to estimate the carbon reserves, their origin and evolution under various rotations currently practised in the rolling pampas. The SOM dynamics will be modelled in a second paper [2].

\section{Materials and methods}

The data used in this work came from two mediumterm experiments run by INTA (Instituto Nacional de Tecnologia Agropecuaria). There was one crop rotation experiment carried out at the Oliveros Experimental Station $\left(33^{\circ} 01^{\prime} \mathrm{S} ; 61^{\circ} 10^{\prime} \mathrm{W}\right)$ and one soybean monoculture experiment carried out at the Pergamino Experimental Station $\left(33^{\circ} 56^{\prime} \mathrm{S} ; 60^{\circ} 34^{\prime} \mathrm{W}\right)$. These two experiments were situated in the central part of the humid Argentinean pampas region, in a natural subregion called the rolling pampas, the soils of which were developed on a thick loess. This work is concerned with the results of the first 13 years of the two experiments.

\subsection{The Oliveros experiment}

The soil, of silty clay texture, is an aquic Argiudoll (USDA classification) of the Oliveros series [30], or a luvic Phaozem (FAO classification). The experiment was established in 1980 on a 2-year-old pasture, on a plot with an agricultural history of 60 years of cropping. At the start of the experiment the soil carbon content was $19 \mathrm{mg} \mathrm{g}^{-1}[6,7]$. The original pasture was kept as a control; it was made up mainly of clover (Trifolium repens L.), chicory (Chicorum intivum L.) and sorghum (Sorghum halepense L.). The carbon analyses performed in 1992 on the control (pasture) did not show any significant differences from the values found at the start in $1980[6,7]$.

The treatments studied were:

w: wheat monoculture;

$\mathrm{m}$ : maize monoculture;

w/s: wheat/soybean rotation, with two crops per year; w/s-m: wheat/soybean-maize, with three crops every 2 years;

w/s-f: wheat/soybean-sunflower, with three crops every 2 years.

The experiment was arranged in randomised blocks with three replications. The mean soil texture, estimated from 18 samples, is as follows: clay $21.2 \pm 0.9 \%$; fine silt $40.2 \pm 0.9 \%$; coarse silt $34.8 \pm 1.6 \%$; sand $3.8 \pm$ $0.2 \%$.

Cultural practices were very similar to those of the local farmers. Methods of ploughing, seedbed preparation, sowing, mechanical weed control, herbicide application and harvesting are given by Bodrero et al. $[6,7]$. The number of soil tillage operations per rotation was on average 7 for wheat, 9 for maize, 12 for the wheat/ soybean sequence, 10 for the wheat/soybean-maize sequence and 10 for the wheat/soybean-sunflower sequence.

Each soil sample was made up of 15 sub-samples, taken before sowing. Sampling was performed to the depth of the plough layer $(0-16 \mathrm{~cm})$. For years 8 and 9 of the wheat/soybean and wheat/soybean-sunflower rotations and for year 8 of the maize monoculture, samples were taken from the $0-20 \mathrm{~cm}$ depth. The samples were air-dried and sieved to $2 \mathrm{~mm}$. The bulk density was not determined at every sampling date because the measurements made at three dates were not significantly different either between replicates or between treatments $[6,7]$.

The experiment contained three replications per treatment (one per block) until 1989, and then six replications per treatment (two per block) thereafter. The control was sampled in 1992, with three replications per block. The samples from the 13 years were stored dry and analysed in 1993. The carbon contents were calculated for the thickness of the plough layer.

\subsection{The Pergamino experiment}

This experiment involved a soybean monoculture grown on a grassland soil without any previous history 
of ploughing. The soil is a typic Argiudoll (USDA) or a luvic Phaozem (FAO) of the Pergamino series [29] of silty texture (clay $22.4-25.2 \%$; silt $61.6-63.2 \%$; sand $13.2-14.2 \%$ ). Weeds which appeared during the soybean crop were controlled chemically. Those which appeared between successive crops and which exhibited C3 metabolism were controlled by hoeing. Three soil samples from the $A_{p}$ and $A_{12}$ horizons were taken in 1990 and 1993 in the soybean plot after harvest and in the adjacent grassland. Each soil sample was made up of 15 sub-samples. The samples were air-dried and sieved to $2 \mathrm{~mm}$. The bulk density was determined at each sampling date over the profile, with six replications per layer. The $\mathrm{C}$ contents were calculated for a soil depth corresponding to an $A_{1}$ horizon mass of $2500 \mathrm{Mg} \mathrm{ha}^{-1}$.

\subsection{Estimations and measurements}

The masses of $\mathrm{C}$ applied in the crop residues are given in table $I$. They were estimated from measured crop yields and harvest indices ([18, 19, 23, 39], Pedrol, pers. comm.) (table II). The above-ground dry matter of the weeds was estimated at between 0 and $2 \mathrm{Mg} \mathrm{C}$ $\mathrm{ha}^{-1}$ year-1 in the maize monoculture (main weed $=$ Sorghum halepense $\mathrm{L}$., a C4 plant), and at 0.5 $\mathrm{Mg} \mathrm{C} \mathrm{ha-1}$ year $^{-1}$ in the wheat monoculture (main weed $=$ Avena fatua $\mathrm{L}$., a C3 plant).

The contribution of the root mass was estimated at $30 \%$ of the aerial biomass for wheat and maize (including rhizodeposition) and $15 \%$ of the aerial biomass for sunflower and soybean. The $\mathrm{C}$ content of the crop residues was taken to be $40 \%$ of their dry matter.

Further, the $\mathrm{N}$ contents of the crop residues (wheat, soybean, maize, sunflower, sorghum) were measured by elemental analysis (Carlo Erba NA 1500). Their biochemical composition was determined by the method of Van Soest and Wine [47] (table II).

The total carbon contents and ${ }^{13} \mathrm{C}$ isotopic abundance of the soils was determined by mass spectrometry (VG SIRA9) coupled with a carbon analyser (Carlo Erba NA1500) using the technique described by Marshall and Whiteway [33]. The ${ }^{13} \mathrm{C}$ natural abundance was expressed in $\delta$ units in relation to PDB reference (Pee Dee Belemnite) via the international standard NBS19, as a function of the isotopic ratio ${ }^{13} \mathrm{C} /{ }^{12} \mathrm{C}$ :

$$
\delta^{13} C=10^{3} \frac{\left(\frac{{ }^{13} C}{{ }^{12} C}\right)-\left(\frac{{ }^{13} C}{{ }^{12} C}\right)_{P D B B}}{\left(\frac{{ }^{13} C}{C}\right)_{P D B}}
$$

Each sample was analysed at least twice. The analysis was repeated when the difference between replicates from a single sample was more than $0.3 \%$.

We will call the carbon from the SOM derived from crop residues applied since $t=0$, i.e. the beginning of the experiment, 'young C'. If one designates by: $\delta_{1}$, the $\delta^{13} \mathrm{C}$ value of the crop residues applied since time $t=0$; $\delta_{0}$, the $\delta^{13} \mathrm{C}$ value of the SOM at time $t=0$ (estimated from the control); $\delta$, the $\delta^{13} \mathrm{C}$ value of the SOM at the sampling time $t$, then the proportion $\alpha(\%)$ of young $\mathrm{C}$ in relation to total soil $\mathrm{C}$ is the following:

$$
\alpha=100\left(\frac{\delta-\delta_{0}}{\delta_{1}-\delta_{0}}\right)
$$

In reality, the values of $\delta_{0}$ and $\delta_{1}$ are not always directly known, so these reference values have to be estimated. In our experiments, $\delta_{0}$ was not measured on the soil samples taken at time $t=0$. At Pergamino, we have taken the value of the grassland control $\left(\delta_{o}=-19.6 \%\right.$ o $)$ assuming that its isotopic composition had hardly altered during the course of the experiment as it was a virgin pasture. At Oliveros, the value found was $-17.5 \%$. However, as the equilibrium hypothesis was less certain than at Pergamino, we have sought the most likely value by simulation, by comparing rotations (see Results).

As to the value of $\delta_{1}$, the best estimate would be that obtained from the analysis of a similar soil, the SOM of which was in isotopic equilibrium with the new vegetation studied [5]. However, the only estimate of $\delta_{1}$ which could be used in our case is the $\delta_{1}$ measured on the new vegetation itself. The isotopic composition measured on the aerial parts of the crops present in our experiments was $-26.3 \%$ for wheat and soybean, $-27.5 \%$ for sunflower and $-11.6 \%$ for maize.

The calculation of $\alpha$ will be made on four of the five rotations present at Oliveros: wheat, maize, wheat/soybean and wheat/soybean-sunflower, because wheat/soybean-maize rotation is a mixture of species having $\mathrm{C} 3$ (wheat, soybean) and $\mathrm{C} 4$ (maize) photosynthetic cycles. In the rotations containing $\mathrm{C} 3$ plants we will take for $\delta_{1}$ the weighted mean of the isotopic compositions of the crops considered.

The 'old' carbon is calculated as the difference between the total $\mathrm{C}$ content and the young $\mathrm{C}$ content. Analysis of variance was performed at Oliveros on the variables: total carbon content and old and young carbon content, year by year. 


\section{Results and discussion}

\subsection{Evolution of $\mathrm{C}$ reserves under the different rotations}

\subsubsection{The Oliveros experiment}

The experiment was established after ploughing in a 2-year pasture in a plot which had experienced 60 years of agriculture. The $C$ reserves show a continuous fall throughout the experiment for all the rotations (figure 1). Analysis of variance shows that there are no significant differences in $\mathrm{C}$ reserves between rotations for a given year.

The masses of $\mathrm{C}$ applied varied between 2 and 7 $\mathrm{Mg} \mathrm{ha}^{-1}$ (table I) with a maximum in years 3 and 4. The wheat/soybean rotation and the maize monoculture provided the highest residue returns. The greatest variability is seen in the two rotations with maize ( $w / s-m$ and $m$ ); this may arise from the difficulty of sampling the maize residues and the presence of Sorghum halepense.

Several authors have found that carbon reserves decline as the frequency of soybean in the rotation increases (e.g. [48]). This fall has been attributed to the low productivity of soybean and hence to low residue returns. In our case, the wheat/soybean rotation did not cause any greater fall in the soil $\mathrm{C}$ content compared with the other rotations. This resulted from the large carbon returns (5.0 $\mathrm{Mg} \mathrm{ha}^{-1}$ ) which are increased due to the succession of wheat and soybean crops in the same year.

Broder and Wagner [9] found that soybean residues decomposed more rapidly than those of maize or wheat. This could be explained by their high $\mathrm{N}$ content and the lower $\mathrm{C} / \mathrm{N}$ and lignin/ $\mathrm{N}$ ratios than for the other residues present in our rotations (table $I I$ ). Moreover, because of their low $\mathrm{C} / \mathrm{N}$ ratio, soybean residues could also stimulate the mineralisation of the rest of the SOM.

Assuming that organic equilibrium is reached after 13 years of continuous cropping, it seems that annual residue returns of about $3-4 \mathrm{Mg} \mathrm{C}$ $\mathrm{ha}^{-1}$ year ${ }^{-1}$ coming from the $\mathrm{w}, \mathrm{w} / \mathrm{s}-\mathrm{m}$ and $\mathrm{w} / \mathrm{s}-\mathrm{f}$ rotations, $4.5 \mathrm{Mg} \mathrm{C} \mathrm{ha}^{-1}$ year $^{-1}$ from the maize, or $5 \mathrm{Mg} \mathrm{C} \mathrm{ha}^{-1}$ year $^{-1}$ from the w/s rotation would be enough to maintain the soil $\mathrm{C}$ reserve at $31 \mathrm{mg} \mathrm{ha}^{-1}$. These values may be compared with various results in the literature. Table III gives values of the $\mathrm{C}$ applications needed to maintain the

Table I. Annual $\mathrm{C}$ inputs to the soil $\left(\mathrm{Mg} \mathrm{ha}^{-1} \mathrm{year}^{-1}\right)$ from the crop residues (aboveground + belowground) and rhizodeposits in five cropping sequences studied at Oliveros.

\begin{tabular}{|c|c|c|c|c|c|c|c|}
\hline \multirow[b]{2}{*}{ Year } & \multirow[t]{2}{*}{ w } & \multirow[t]{2}{*}{$\mathrm{w} / \mathrm{s}$} & \multirow[t]{2}{*}{$\mathrm{w} / \mathrm{s}-\mathrm{f}$} & \multirow[t]{2}{*}{$\begin{array}{l}\text { Crop sequence } \\
\text { w/s-m }\end{array}$} & \multicolumn{2}{|c|}{$\mathrm{m}$} & \multirow[b]{2}{*}{ Total } \\
\hline & & & & & $\begin{array}{l}\text { Sorghum } \\
\text { halepense }\end{array}$ & $\begin{array}{l}\text { Zea } \\
\text { mais }\end{array}$ & \\
\hline 1 & 2.27 & 3.84 & 3.18 & 3.41 & 1.00 & 4.25 & 5.25 \\
\hline 2 & 4.27 & 5.53 & 3.35 & 2.79 & 1.40 & 3.35 & 4.75 \\
\hline 3 & 4.51 & 7.09 & 4.07 & 4.71 & 1.70 & 4.53 & 6.23 \\
\hline 4 & 3.28 & 6.10 & 3.97 & 5.67 & 2.60 & 3.44 & 6.04 \\
\hline 5 & 2.10 & 4.57 & 2.96 & 2.46 & 2.80 & 1.45 & 4.25 \\
\hline 6 & 2.22 & 5.27 & 3.28 & 6.64 & 1.80 & 3.06 & 4.86 \\
\hline 7 & 2.03 & 4.57 & 2.95 & 2.22 & 1.60 & 2.48 & 4.08 \\
\hline 8 & 3.14 & 3.56 & 3.66 & 3.83 & 2.00 & 0.50 & 2.50 \\
\hline 9 & 2.41 & 4.69 & 2.72 & 2.72 & 1.90 & 0.87 & 2.77 \\
\hline Average & 2.91 & 5.02 & 3.35 & 3.83 & 1.87 & 2.66 & 4.53 \\
\hline SD & $(0.95)$ & (1.11) & $(0.47)$ & $(1.54)$ & $(0.56)$ & $(1.44)$ & $(1.29)$ \\
\hline
\end{tabular}

In the continuous maize treatment $(\mathrm{m})$, the contributions from weed Sorghum halepense and from maize are given separately. 
Table II. Mean harvest index of the crop, $\mathrm{N}$ content, $\mathrm{C} / \mathrm{N}$ ratio and chemical composition (Van Soest analysis) of crop residues.

\begin{tabular}{|c|c|c|c|c|c|c|c|}
\hline \multirow[t]{2}{*}{ Crop } & \multirow[t]{2}{*}{ Harvest index } & \multirow{2}{*}{$\begin{array}{c}\mathrm{N} \text { content } \\
(\%)\end{array}$} & \multirow[t]{2}{*}{$\mathrm{C} / \mathrm{N}$} & \multicolumn{4}{|c|}{ Chemical composition } \\
\hline & & & & $\operatorname{NDF}(\%)$ & $\operatorname{HCEL}(\%)$ & CELL $(\%)$ & $\operatorname{LIG}(\%)$ \\
\hline Wheat & 0.36 & 0.39 & 97 & 19.5 & 36.8 & 36.2 & 7.5 \\
\hline Maize & 0.40 & 0.39 & 87 & 20.9 & 39.8 & 29.5 & 9.8 \\
\hline Soybean & 0.38 & 0.90 & 44 & 34.4 & 23.9 & 31.1 & 10.6 \\
\hline Sunflower & 0.23 & 0.81 & 49 & 52.1 & 14.3 & 21.5 & 12.1 \\
\hline Sorgho & - & - & - & 45.9 & 25.8 & 24.3 & 4.0 \\
\hline
\end{tabular}

$\mathrm{NDF}=$ neutral detergent soluble fraction, $\mathrm{HCEL}=$ hemicelluloses, $\mathrm{CELL}=$ cellulose, $\mathrm{LIG}=$ lignin.

Table III. Mean temperature, organic C content in soil and annual $\mathrm{C}$ addition required for soil organic carbon maintenance in different pedoclimatic conditions.

\begin{tabular}{lcccc}
\hline Site & $\begin{array}{c}\text { Average annual } \\
\text { temperature }\left({ }^{\circ} \mathrm{C}\right)\end{array}$ & $\begin{array}{c}\text { Soil organic } \mathrm{C} \text { at } \\
\text { steady state }\left(\mathrm{Mg} \mathrm{ha}^{-1}\right)\end{array}$ & $\begin{array}{c}\text { Annual C addition } \\
\left(\mathrm{Mg} \mathrm{ha}^{-1} \text { year }\right.\end{array}$ & Reference \\
\hline Uppsala (Sweden) & 5 & 37 & 1.6 & {$[40]$} \\
Broadbalk (England) & 9 & 30 & 1.7 & {$[31]$} \\
Oregon (USA) & 10 & 47 & 2.0 & {$[42]$} \\
Grignon (France) & 11 & 49 & 3.0 & {$[35]$} \\
Boigneville (France) & 11 & 35 & 3.6 & {$[25]$} \\
Landes (France) & 13 & 27 & $3-5$ & {$[41]$} \\
Oliveros (Argentine) & 18 & 31 & 1.1 & this paper \\
Queensland (Australia) & 19 & 8 & 4.7 & {$[21]$} \\
Sao Paulo (Brazil) & $20-24$ & 38 & & {$[16]$} \\
\hline
\end{tabular}

level of reserves at equilibrium for different situations. This table suggests that, except for the very dry climate of Queensland, the higher the mean temperature, the greater are the amounts of $\mathrm{C}$ needed to maintain the equilibrium. The values found at Oliveros are in agreement with these figures, the mean temperature being in the order of $18^{\circ} \mathrm{C}$.

\subsubsection{The Pergamino experiment}

In this experiment, the starting situation was the original grassland with a very high $\mathrm{C}$ reserve $\left(68 \mathrm{mg} \mathrm{Cha}^{-1}\right)$. Over the course of the first 13 years of cropping (soybean monoculture) the $\mathrm{C}$ reserve fell sharply to $49 \mathrm{Mg} \mathrm{ha}^{-1}$, which is a loss of $28 \% \mathrm{C}$ in $2500 \mathrm{Mg} \mathrm{ha}^{-1}$ of soil (figure 2).

The masses of $\mathrm{C}$ applied (table $I V$ ) do not show much year to year variation because the monocul- ture was grown on a very fertile soil without nutritional limiting factors. In the absence of limitations due to weather, the yields are therefore stable and high. However, although the amounts of soybean residues applied are large $(3.8 \mathrm{mg} \mathrm{C} \mathrm{ha-1} \mathrm{year-1)}$ and can be in the same order of magnitude as under grassland, they are not enough to maintain soil $\mathrm{C}$ reserves at their original level.

The cultivation of grassland soils provokes a breakdown of the organic equilibrium. This can be the result of accelerated decomposition of the soil organic C. Certain authors $[8,10,14]$ explain that the rapid mineralisation which follows the destruction of the grassland is at least partly due to a change in the composition of the SOM. Free organic matter, visible or easily mineralisable (roots, rootlets, soluble compounds and prehumic prod- 

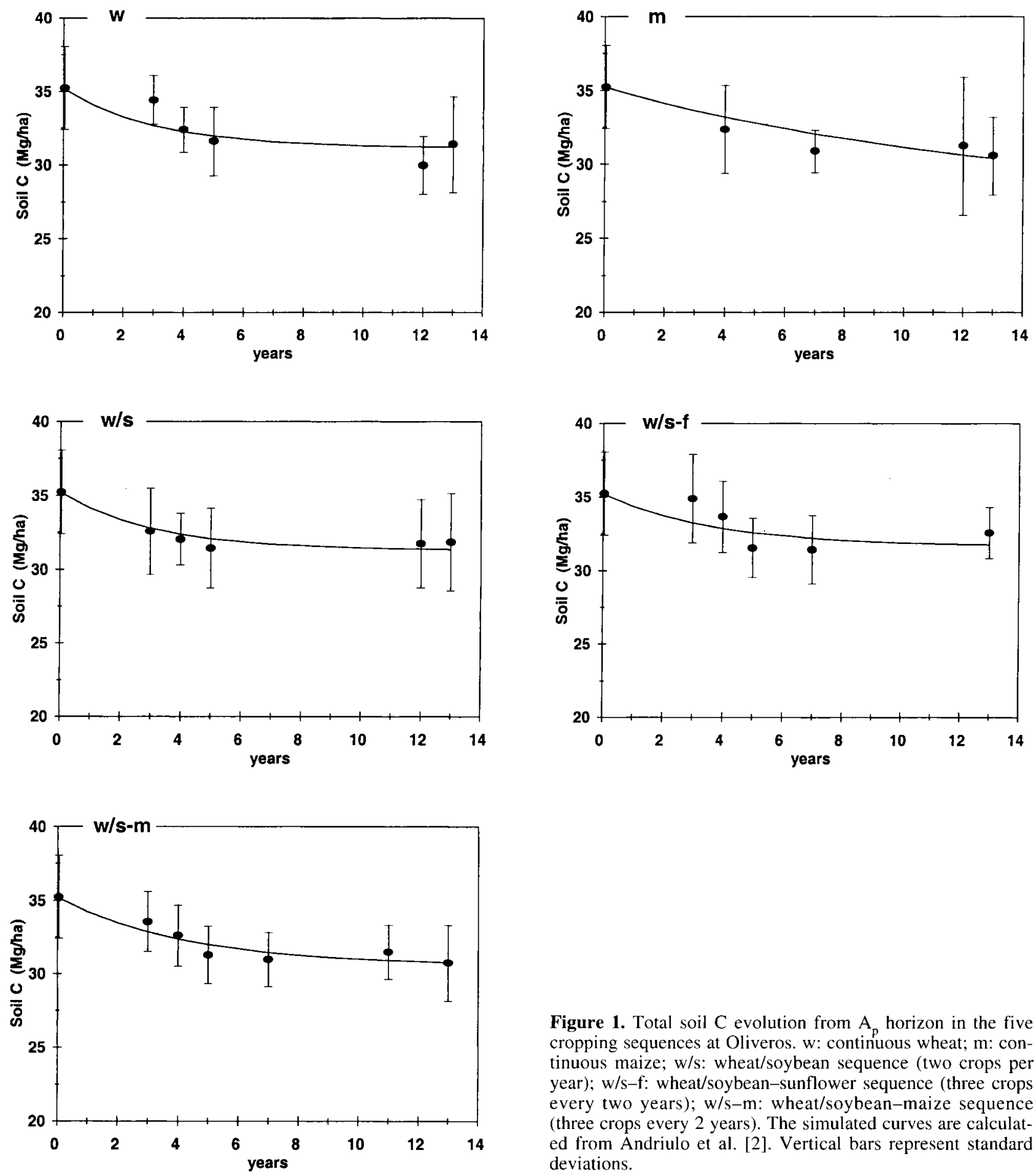

Figure 1. Total soil $C$ evolution from $A_{p}$ horizon in the five cropping sequences at Oliveros. w: continuous wheat; $\mathrm{m}$ : continuous maize; w/s: wheat/soybean sequence (two crops per year); w/s-f: wheat/soybean-sunflower sequence (three crops every two years); w/s-m; wheat/soybean-maize sequence (three crops every 2 years). The simulated curves are calculated from Andriulo et al. [2]. Vertical bars represent standard deviations. 


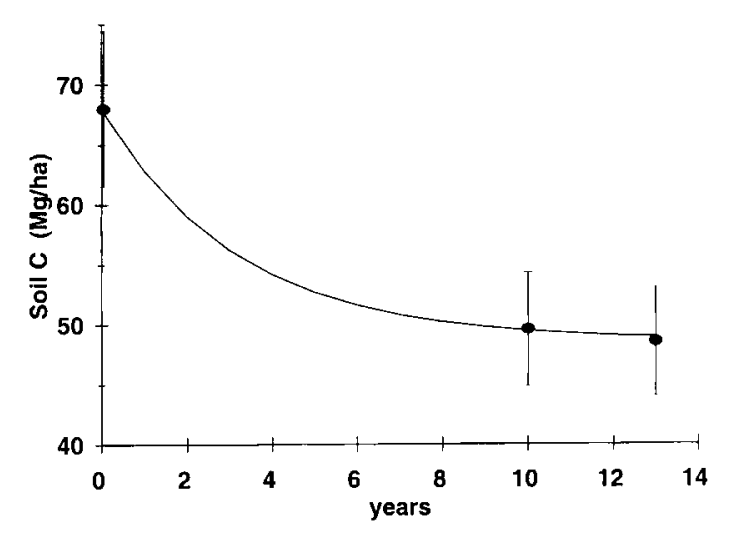

Figure 2. Evolution of total soil $\mathrm{C}$ at Pergamino under continuous soybean. Total soil carbon is calculated for a $2500 \mathrm{Mg}$ $\mathrm{ha}^{-1}$ soil mass. Vertical bars represent standard deviations. ucts), are present in large amounts under grassland and are liable to intense mineralisation in the early years of cropping. These authors talk of 'supplementary' mineralisation of about $10-15 \%$ of the initial reserve for the early years.

Other factors could explain the changes in the $\mathrm{C}$ content following the start of cultivation.

- A change in the amounts of harvest residues being returned. However, the different amounts returned for the virgin grassland or for different rotations do not seem to be able in themselves to explain the observed differences [1].

- Water erosion. Although this process could be responsible for serious losses in very hilly areas [45] it did not occur in our study. In fact the masses of soil present to the depth of the $\mathrm{B}_{2 \mathrm{t}}$ horizon are identical in the two treatments.

- The deepening of ploughing. This causes mixing of the surface layers with the deeper ones. The surface layers can be diluted by the underlying layers less rich in SOM [28]. In our study, dilution is unlikely because the layer below the cultivated layer, belonging to the same pedological horizon, has a SOM value very similar to that of the plough layer.
Table IV. Amounts of $\mathrm{C}$ annually returned to the soil from soybean residues (aboveground + belowground + rhizodeposition) from the continuous soybean at Pergamino.

\begin{tabular}{lc}
\hline Year & $\begin{array}{c}\text { Annual C inputs } \\
\left(\mathrm{Mg} \mathrm{ha}^{-1} \text { year }^{-1}\right)\end{array}$ \\
\hline 1 & 3.58 \\
2 & 3.21 \\
3 & 3.97 \\
4 & 3.76 \\
5 & 3.79 \\
6 & 4.10 \\
7 & 4.16 \\
8 & 3.08 \\
9 & 4.21 \\
10 & 3.76 \\
Average & 3.76 \\
\hline
\end{tabular}

\subsection{Origin of the carbon determined by natural ${ }^{13} \mathrm{C}$ isotopic tracing}

\subsubsection{Characterisation of the initial state}

The distribution of soil carbon with depth in the original pampas soils is usually like that observed at Pergamino (figure 3). It is similar to the profiles generally seen in grassland soils in temperate climates [11]. The $\mathrm{C}$ content reaches $30 \mathrm{mg} \mathrm{g}^{-1}$ at the surface and remains above $10 \mathrm{mg} \mathrm{g}^{-1}$ at $60 \mathrm{~cm}$. This site has a warm temperate climate (mean annual temperature $17^{\circ} \mathrm{C}$, mean annual rainfall $900 \mathrm{~mm}$ ).

The $\delta^{13} \mathrm{C}$ isotopic composition of the soil organic matter should in principle resemble that of the vegetation from which it is derived. Thus, in the pampas where the original vegetation is grassland made up of a mixture of C3 and C4 grasses [36], the SOM in the surface layers should have about the same $\delta^{13} \mathrm{C}$ value as the vegetation regarded as original. This hypothesis was tested by analysing the main grasses (table $V$ ) and the virgin soil of Pergamino.

Although the botanical composition of the original pampas is difficult to establish with certainty [26], it is likely that the climax vegetation of the original pampas was roughly composed of: $50 \%$ 


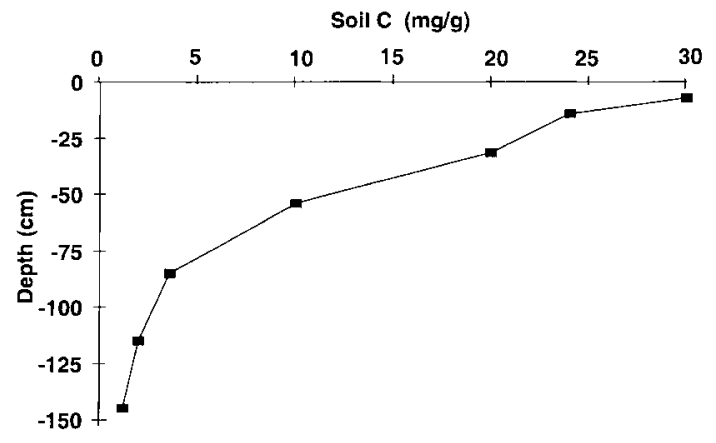

Figure 3. Distribution with depth of soil $\mathrm{C}$ (in $\mathrm{mg} \mathrm{g}^{-1}$ ) in the virgin soil at Pergamino.

Stipa, $40 \%$ Bothriochloa and $10 \%$ Paspalum [32]. This represents equal proportions of $\mathrm{C} 3$ and $\mathrm{C} 4$ plants, for which one can estimate the mean isotopic composition:

$$
\begin{aligned}
\delta^{13} \mathrm{C} & =(-29.03 * 0.50)+(-12.0 * 0.40) \\
& +(-12.8 * 0.10)=-20.6 \%
\end{aligned}
$$

The mean $\delta^{13} \mathrm{C}$ isotopic composition measured in the $A_{11}$ horizon is $-19.6 \%$. The hypothesis just proposed therefore seems to be acceptable.

The Oliveros experiment began at the end of a 60 -year period of agriculture with alternating cycles of crops and pasture. The initial $\delta^{13} \mathrm{C}$ value is not known. It has been estimated from the measurement made in the adjacent grassland 12 years after the start of the experiment. The mean value for this reference site is $-17.5 \pm 0.4 \%$. However, we do not know whether there was equilibrium at time zero between the $\delta^{13} \mathrm{C}$ value of the SOM and that of the vegetation. Even if the initial $\mathrm{C}$ and $\mathrm{N}$ contents were very similar to those measured on the control, it is possible that the $\delta^{13} \mathrm{C}$ value of the chosen reference might differ from the starting value. It would therefore be advisable to question the starting value of $\delta^{13} \mathrm{C}$, for the Oliveros experiment, in our calculations of young and old C.

\subsubsection{The Oliveros experiment}

Table VI shows the evolution of the soil $\delta^{13} \mathrm{C}$ in the four rotations of the Oliveros experiment. As
Table V. Natural $\delta^{1.3} \mathrm{C}$ abundance $(\% 0)$ of the major graminaceae found in the native prairie in the Rolling Pampa.

\begin{tabular}{ll}
\hline Pampa Graminaceae & $\delta^{13} \mathrm{C}$ \\
\hline Hordeum stenotachis & -25.6 \\
Poa sp. & -30.9 \\
Briza subaristata & -29.9 \\
Stipa papposa & -29.3 \\
Stipa hyalina & -29.6 \\
Deyeuxia sp. & -28.2 \\
Bromus unioloides (naturalisée) & -29.8 \\
Lolium multiflorum (naturalisée) & -32.0 \\
Stipa neesiana & -28.2 \\
Paspalum dilatatum & -12.8 \\
Paspalum urvillei & -12.7 \\
Setaria geniculata & -12.2 \\
Chloris polydactila & -12.8 \\
Paspalum notatum & -12.1 \\
Bothriochloa laguroides & -12.0 \\
\hline
\end{tabular}

Table VI. Natural $\delta^{13} \mathrm{C}$ abundance (\%o) of the soil $(0-20 \mathrm{~cm})$ measured in four cropping sequences at Oliveros.

\begin{tabular}{lcccc}
\hline \multicolumn{5}{c}{ Cropping sequence } \\
Year & $w(\mathrm{C} 3)$ & $\mathrm{m}(\mathrm{C} 4)$ & $\mathrm{w} / \mathrm{s}(\mathrm{C} 3)$ & w/s-f (C3) \\
\hline 1983 & $-18.1(0.1)$ & & $-18.5(0.2)$ & $-18.6(0.1)$ \\
1984 & $-18.2(0.3)$ & $-17.0(0.0)$ & $-18.7(0.3)$ & $-18.7(0.1)$ \\
1985 & $-18.2(0.2)$ & & $-19.0(0.2)$ & $-18.9(0.1)$ \\
1987 & & $-16.4(0.0)$ & & $-18.5(0.1)$ \\
1988 & $-16.4(0.3)$ & $-18.8(0.1)$ & $-18.5(0.1)$ \\
1989 & & & $-18.9(0.1)$ & $-18.9(0.1)$ \\
1992 & $-18.4(0.1)$ & $-15.7(0.2)$ & $-19.3(0.3)$ & \\
1993 & $-18.4(0.1)$ & $-15.5(0.5)$ & $-19.4(0.2)$ & $-19.5(0.2)$
\end{tabular}

Standard deviations are given in brackets.

expected, the rotations with C3 plants have caused a fall in the $\delta^{13} \mathrm{C}$ values over the course of time, whereas the maize monoculture $(\mathrm{C} 4)$ has increased them.

We found that the evolution of $\delta^{13} \mathrm{C}$ over time was sufficiently sensitive to allow us to calculate the contributions of young and old carbon, both for the rotations with $\mathrm{C} 3$ and $\mathrm{C} 4$ plants. The calcula- 
tion of the proportion of young $\mathrm{C}$ depends on the $\delta^{13} \mathrm{C}$ value at the start (equation (2)). To test the sensitivity to this initial value, we have calculated the young $\mathrm{C}$ and the old $\mathrm{C}$ by using the following four values of $\delta^{13} \mathrm{C}$ bracketing the mean.

- Taking the highest $\delta^{13} \mathrm{C}$ value found among the samples: $-17.1 \%$.

- Assuming that the old carbon reserve was the same for all rotations. This gives a value for $\delta^{13} \mathrm{C}_{0}=-17.3 \%$.

- Using the mean measured value at $t=12$ years: $\delta^{13} \mathrm{C}_{0}=-17.5 \%$.
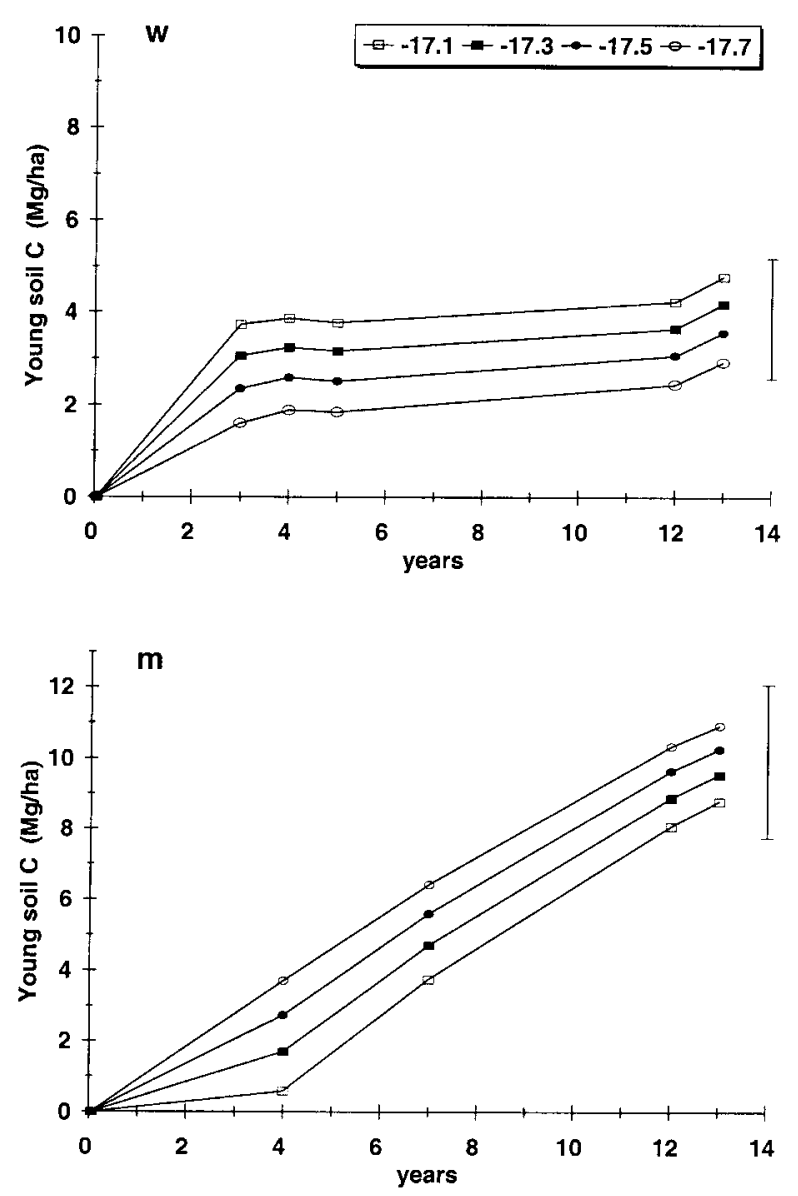

- Using a value lower than the mean: $\delta^{13} \mathrm{C}_{0}=-17.7 \%$.

Figure 4 shows the evolution of the young $\mathrm{C}$ content for each treatment calculated for these four values. In the maize monoculture, the value $\delta^{13} C_{0}=-17.1 \%$ gives an estimate of the amount of young $\mathrm{C}$, at $t=4$ years, which is low considering the large amounts of maize residues applied to the soil (table I) and low in comparison with the wheat monoculture which should be similar to it. This observation leads us to reject this hypothesis.

Conversely, the value of $\delta^{13} \mathrm{C}_{0}=-17.7 \%$ gives a very high estimate of young $\mathrm{C}$ coming from maize (11 $\mathrm{mg} \mathrm{C} \mathrm{ha}^{-1}$ ) and a very low one ( $\mathrm{mg} \mathrm{Cha}^{-1}$ )
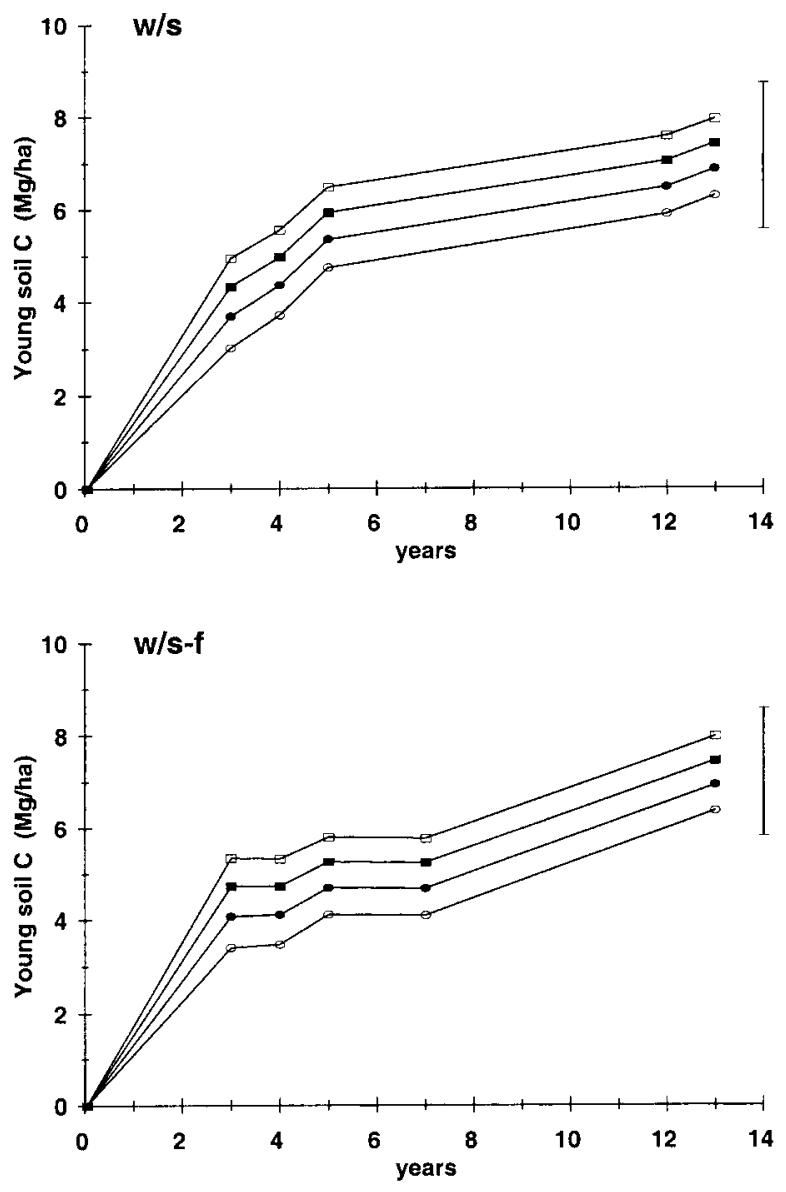

Figure 4. Evolution of 'young C' calculated for four possible values of soil $\delta^{13} \mathrm{C}$ at $t=0$. Vertical bars represent standard deviations. 
for wheat. This is unlikely in view of the amount of residues returned and leads us to reject the value $-17.7 \%$.

The remaining possible values of $\delta^{13} \mathrm{C}_{0}$ of -17.3 or $-17.5 \%$ are retained. They result in the following order of classification for the young $\mathrm{C}$ reserves: $\mathrm{w}<\mathrm{w} / \mathrm{s}<\mathrm{w} / \mathrm{s}-\mathrm{f}<\mathrm{m}$, at the end of 13 years. We find that the accumulation of young $C$ over the course of time shows the following two different trends.

- For the $w, w / s$ and $w / s-f$ rotations, the incorporation of young $\mathrm{C}$ is very quick during the first 3 years and then reaches a plateau. This is due to a big drop in yields and thus in residues returned (table I).

- For the maize monoculture $(\mathrm{m})$, in spite of a fall in yields and thus of returns (table I), the young $\mathrm{C}$ content increases regularly. The progressive appearance of Sorghum halepense (also a C4 plant with $\delta^{13} \mathrm{C}=-12 \%$ ) added to the residues. This contribution can be estimated at $1.4 \mathrm{mg} \mathrm{C} \mathrm{ha}^{-1}$ year $^{-1}$ for the first 3 years, i.e. $25 \%$ of the mass of $\mathrm{C}$ added annually, and then
$2.1 \mathrm{mg} \mathrm{C} \mathrm{ha}^{-1}$ year $^{-1}$ from year 4 to year 9 , i.e. $56 \%$ of the mass of $\mathrm{C}$ applied annually. Unfortunately we do not have data for the succeeding years.

The reserve of young $\mathrm{C}$ accumulated by the end of the experiment is practically identical in the rotations $w / s-f$ and $w / s$, although the amount of residues returned each year from the $w / s-f$ rotation were $30 \%$ less than from the w/s rotation. The higher lignin content of sunflower could explain this accumulation of young carbon.

Figure 5 shows the changes in old $\mathrm{C}$ content on each treatment calculated with the two initial $\delta^{13} \mathrm{C}$ values which were retained. A general exponentialtype trend is apparent for the $\mathrm{C}$ evolution on all the rotations. The soybean crop induced a slightly faster decrease in the old $\mathrm{C}$ content $(30 \%$ higher in $\mathrm{w} / \mathrm{s}$ than in $\mathrm{w}$ ), confirming the previously mentioned depressive effect of soybean [17]. During the first 5 years the quantities of $\mathrm{C}$ mineralised were greater than the quantities of $\mathrm{C}$ humified. Except for the maize monoculture, each rotation showed signs after 5 years of a new equilibrium

Table VII. Turnover times calculated for old soil organic $\mathrm{C}$ and young soil organic $\mathrm{C}$ using natural $\delta^{13} \mathrm{C}$ abundance method in various sites recently cultivated.

\begin{tabular}{|c|c|c|c|c|c|c|c|c|c|}
\hline Location & $\begin{array}{l}\text { Previous } \\
\text { vegetation/ } \\
\text { current crop }\end{array}$ & $\begin{array}{c}\text { Duration } \\
\text { (years) } \\
\left({ }^{\circ} \mathrm{C}\right)\end{array}$ & $\begin{array}{l}\text { Depth } \\
(\mathrm{cm})\end{array}$ & $\begin{array}{l}\text { Mean annual } \\
\text { temperature }\end{array}$ & $\begin{array}{l}\text { Annual C input } \\
\left(\mathrm{Mg} \mathrm{ha}^{-1} \text { year }^{-1}\right)\end{array}$ & $\begin{array}{l}\text { Young } \\
\text { soil C } \\
\left(\mathrm{Mg} \mathrm{ha}^{-1}\right)\end{array}$ & $\begin{array}{c}\text { Young } \mathrm{C} / \\
\text { annual } \mathrm{C} \\
\text { addition/duration }\end{array}$ & $\begin{array}{l}\text { TRM old C } \\
\text { (years) }\end{array}$ & Reference \\
\hline $\begin{array}{l}\text { Piracicaba } \\
\text { (Brazil) }\end{array}$ & $\begin{array}{c}\text { forest/ } \\
\text { sugar cane }\end{array}$ & 12 & $0-20$ & 24 & $4.7 * *$ & 8.6 & 0.15 & 17 & {$[16]$} \\
\hline $\begin{array}{l}\text { Central Amazon } \\
\text { (Brazil) }\end{array}$ & $\begin{array}{l}n \text { forest/ } \\
\text { Brachiaria }\end{array}$ & 8 & $0-20$ & 26 & 37.5 & 45.8 & 0.15 & 12 & {$[20]$} \\
\hline $\begin{array}{l}\text { Eastern Amazon } \\
\text { (Brazil) }\end{array}$ & $\begin{array}{l}n \text { forest/ } \\
\text { Pennisetum }\end{array}$ & 10 & $0-20$ & 27 & 11.3 & 11.8 & 0.10 & 17 & [22] \\
\hline $\begin{array}{l}\text { Ontario } \\
\text { (Canada) }\end{array}$ & $\begin{array}{c}\text { forest/ } \\
\text { corn }\end{array}$ & 25 & $0-30$ & $8.5^{*}$ & 4.0 & 21.6 & 0.22 & 34 & [24] \\
\hline $\begin{array}{l}\text { Quebec } \\
\text { (Canada) }\end{array}$ & $\begin{array}{c}\text { prairie/ } \\
\text { sillage corn }\end{array}$ & 11 & $0-24$ & $7.5^{*}$ & 1.4 & 4.5 & 0.30 & 36 & [3] \\
\hline $\begin{array}{l}\text { Pergamino } \\
\text { (Argentina) }\end{array}$ & $\begin{array}{c}\text { prairie/ } \\
\text { soybean }\end{array}$ & 13 & $0-21$ & 17 & 3.8 & 6.6 & 0.13 & 24 & this paper \\
\hline
\end{tabular}

\footnotetext{
* The average annual temperature was calculated by supposing that negative temperatures are equivalent to $0{ }^{\circ} \mathrm{C}$ for organic matter decomposition.

** The annual $\mathrm{C}$ input was obtained by curve fitting.
} 

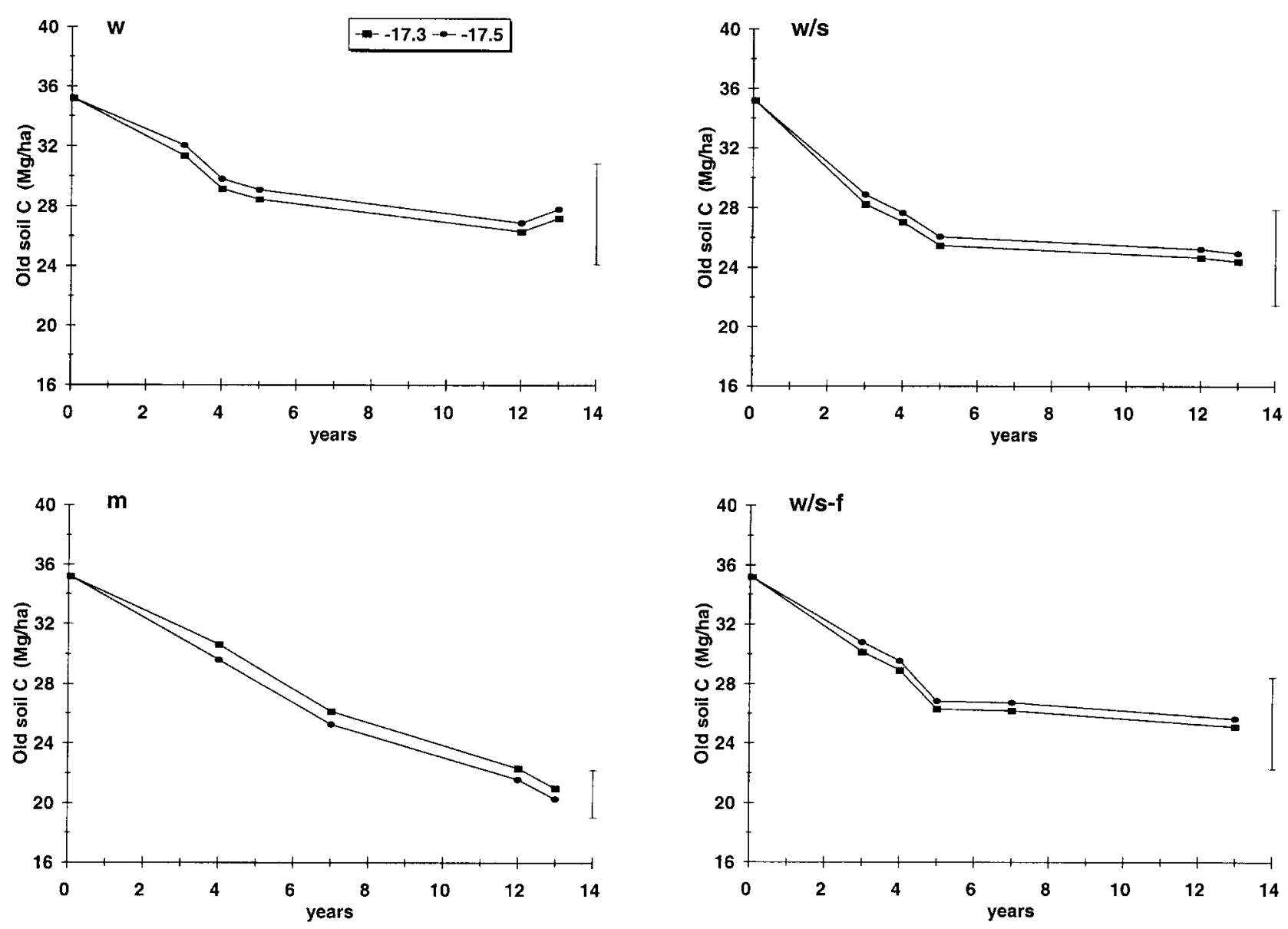

Figure 5. Evolution of 'old C' calculated for two possible values of soil $\delta^{13} \mathrm{C}$ at $t=0$. Vertical bars represent standard deviations.

state related to the nature and quantity of returned residues.

\subsubsection{The Pergamino experiment}

Figure 6 shows the distribution of young and old $\mathrm{C}$ after 10 or 13 years of soybean monoculture at Pergamino. The old $\mathrm{C}$ fell by $37 \%$ in 13 years of soybean cropping. This large fall confirms the effects of this crop on soil $\mathrm{C}$ mineralisation. It probably results from the combined effect of the biochemical composition of soybean and the repeated ploughing after commencing cultivation in the climatic conditions of the pampas.

If one assumes a simple exponential decline

$$
C(t)=C_{0} \exp (-k t)
$$

$C(t)$ being the $\mathrm{C}$ content at time $t, C_{0}$ the $\mathrm{C}$ content at the start and $k$ the rate constant, one can calculate the renewal time for the old $\mathrm{C}(\mathrm{RT}=1 / k)$ [24]. At Pergamino we obtain the value $R T=24$ years. This value can be compared with values given in the literature, observed over the medium term (10-25 years), in a humid climate, after starting cultivation following forest clearing or ploughing of grassland (table VII). This shows that the RT of the old $\mathrm{C}$ varies with the mean temperature figure 7) and that the RT obtained for the pampas fits well into this relationship. 


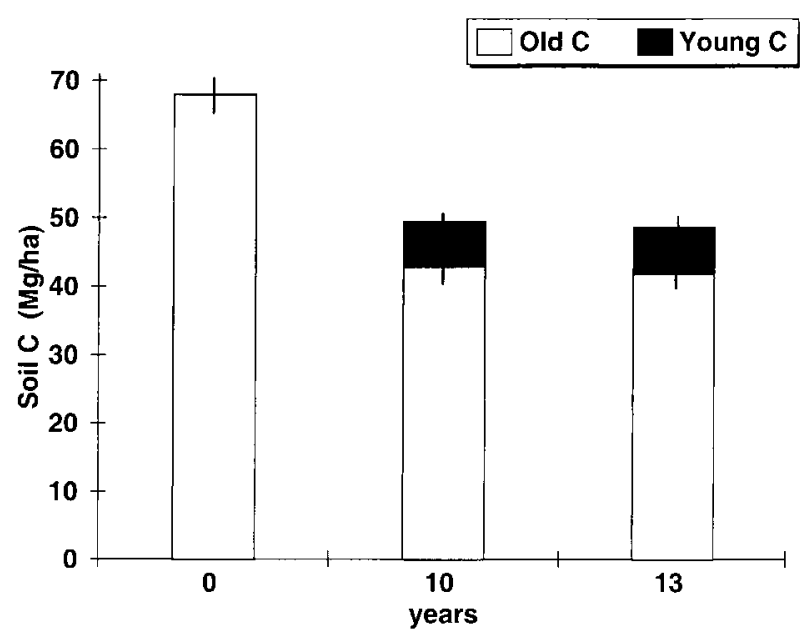

Figure 6. Evolution of 'young' and "old' $C$ contents in soil under continuous soybean at Pergamino.

In the pampas, the young $\mathrm{C}$ content reaches $6.6 \mathrm{mg} \mathrm{ha}^{-1}$ year $^{-1}$ after 13 years of soybean monoculture. If the average amount of $\mathrm{C}$ returned annually is $3.8 \mathrm{Mg} \mathrm{ha}^{-1}$ year $^{-1}$ and if the annual increase in young $\mathrm{C}$ is $0.51 \mathrm{mg} \mathrm{ha}^{-1}$ year $^{-1}$, then the young $\mathrm{C}$ remaining in the soil represents $13 \%$ of the applied $\mathrm{C}$. We find in the literature (table VII) that the accumulation of young $\mathrm{C}$ depends on the mass of $\mathrm{C}$ applied each year and decreases when the mean annual temperature increases. Values of 10-22\% have been reported in studies from France, Brazil and Canada, while a value of $30 \%$ was found in a Canadian study with silage maize in which the residues applied come mostly from roots.

\section{Conclusions}

Cultivation of virgin grassland with soybean monoculture has lead to a big loss of the soil $\mathrm{C}$ reserve. It causes a major imbalance between the return by the soybean and the mineralisation of soil carbon coming from the original grassland, leading to a new equilibrium state for the $C$ reserve after about 10 years. However, it is difficult to distinguish, within the acceleration of mineralisation, the specific effect of altering the biochemical nature of

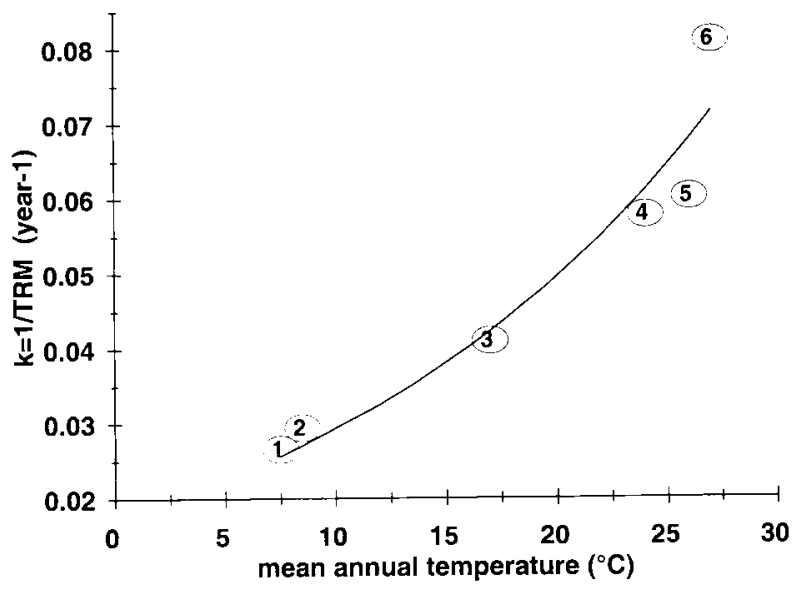

Figure 7. Annual mineralisation rate of 'old' soil $C$ versus average annual temperature at different locations. Each location consists of recent cultivation succeeding to forest or prairie and was studied with natural ${ }^{13} \mathrm{C}$ abundance technique. 1 = Quebec, 2 = Ontario, 3 = Pergamino, 4 = Piracicaba, $5=$ Eastern Amazon, $6=$ Central Amazon.

the residues from that of the reworking of the soil plough layer in the soil/climatic conditions of the rolling pampas. To conclude, we need to characterise the different fractions of the soil carbon better. This study shows that the use of natural isotope tracing using ${ }^{13} \mathrm{C}$ allows the recently incorporated carbon to be clearly differentiated from that which was already present when the change in cropping system took place.

The transition from a system of mixed crop-livestock farming to an arable system leads to a smaller imbalance than the ploughing up of the original grassland. But the different rotations and monocultures studied in this work result in an almost identical carbon reserve at equilibrium, no matter what quantities of residues are returned. This equilibrium seems to be reached after a period of about 5 years in the soil and climatic conditions of the rolling pampas.

From a methodological point of view:

- the use of natural abundance of ${ }^{13} \mathrm{C}$ proves to be a reliable method for studying the carbon reserves in rotations, the crops of which exhibit small differences in $\delta^{13} \mathrm{C}$, i.e. for plants with the 
same photosynthetic cycle ( $\mathrm{C} 3$ or $\mathrm{C} 4$ ), whether they be cultivated plants or weeds;

- if the value of soil $\delta^{13} \mathrm{C}$ at the time of the change in cropping system corresponds to an intermediate value arising from a mixed $\mathrm{C} 3-\mathrm{C} 4$ residue application, it is then possible to demonstrate an increase or decrease in $\delta^{13} \mathrm{C}$ resulting from successive applications of residues of $\mathrm{C} 3$ or $\mathrm{C} 4$ plants, respectively.

This technique, based on the natural abundance of ${ }^{13} \mathrm{C}$, enables the carbon cycle to be modelled, distinguishing different fractions defined by their origin, and estimating the resulting fluxes.

Acknowledgements: This work was possible thanks to a bilateral collaboration contract between Inra and INTA. We thank the scientists and technicians who were kind enough to provide us with soil samples, crop yield data and their agronomic knowledge of the rolling pampas. Thanks to M. Grably, C. Girardin and O. Delfosse for carrying out the analyses at the Isotopic Biogeochemistry Laboratory in Paris and at the Agronomy Unit in Laon, and N. Carnevale for lending his collection of grasses representative of the original pampas flora. Final acknowledgements go to A. Mariotti, D. Angers and J. Balesdent for their scientific support and A. Scaife for the English revision.

\section{References}

[1] Andriulo A., Modélisation de l'évolution des matières organiques des sols de la Pampa. Relation avec les systèmes de culture, thèse INA-PG, Paris, 1995, 143 p.

[2] Andriulo A., Mary B., Guérif J., Modelling the dynamics of soil carbon in various cropping sequences of the rolling pampa, Agronomie 19 (1999) 365-377.

[3] Angers D.A., Voroney R.P., Coté D., Dynamics of soil organic matter and corn residues as affected by tillage practices, Soil Sci. Soc. Am. J. 59 (1995) $1311-1315$.

[4] Balesdent J., Wagner G.H., Mariotti A., Soil organic matter turnover in long-term field experiments as revealed by carbon-13 natural abundance, Soil Sci. Soc. Am. J. 52 (1988) 118-124.

[5] Balesdent J., Estimation du renouvellement du carbone des sols par mesure isotopique ${ }^{13} \mathrm{C}$. Précision, risque de biais, Cahiers Orstom, sér. Pédol. 26 (1991) 315-326.

[6] Bodrero M., Macor L., Demmi M., Vernizzi C., Gonzalez C., Rotaciones agrícoles: I. Influencia sobre el rendimiento del trigo y algunas propiedades físicas y químicas del suelo, in: XIII Cong. Arg. Ciencia del suelo, Trabajos y comunicaciones resumidas, San Carlos de Bariloche, Argentina, 1991, pp. 84-85.

[7] Bodrero M., Macor L., Demmi M., Vernizzi C., Gonzalez C., Papa J.C., Rotaciones agrícoles: II. Influencia sobre el rendimiento del maíz, girasol y soja y algunas propiedades físicas y químicas del suelo, in: XIII Cong. Arg. Ciencia del suelo, Trabajos y comunicaciones resumidas. San Carlos de Bariloche, Argentina, 1991, pp. 85-86.

[8] Boiffin J., Fleury A., Quelques conséquences agronomiques du retournement des prairies permanentes, Ann. Agron. 4 (1974) 555-573.

[9] Broder M.W., Wagner G.H., Microbial colonization and decomposition of corn, wheat and soybean residues, Soil Sci. Soc. Am. J. 52 (1988) 112-117.

[10] Cambardella C.A., Elliott E.T., Particulate soil organic matter changes across a grassland cultivation sequences, Soil Sci. Soc. Am. J. 56 (1992) 777-783.

[11] Campbell C.A., Soil organic carbon, nitrogen and fertility, in: Schnitzer M., Khan S.U. (Eds.), Soil Organic Matter, Elsevier, New York, 1978, pp. 173-272.

[12] Campbell C.A., Bowren K.E., Schnitzer M., Zentner R.P., Townley-Smith L., Effect of crop rotation and fertilization on soil organic matter and some biochemical properties of a thick Black Chernozem, Can. J. Soil Sci. 71 (1991) 377-387.

[13] Campbell C.A., Lafond G.P., Leyshon A.J., Zentner R.P., Janzen H.H., Effect of cropping practices on the initial potential rate of $\mathrm{N}$ mineralization in a thin Black Chernozem, Can. J. Soil Sci. 71 (1991) 43-53.

[14] Campbell C.A., Lafond G.P., Zentner R.P., Biederbeck V.O., Influence of fertilizer and straw baling on soil organic matter in a thin Black Chernozem in western Canada, Soil Biol. Biochem. 23 (1991) 443-446.

[15] Campbell C.A., Zentner R.P., Soil organic matter as influenced by crop rotations and fertilization, Soil Sci. Soc. Am. J. 57 (1993) 1034-1040.

[16] Cerri C.C., Feller C., Balesdent J., Victoria R.L., Plenesassagne A., Application du traçage isotopique naturel en ${ }^{13} \mathrm{C}$ à l'étude de la dynamique de la matière organique dans les sols, C. R. Acad. Sci. 300 (1985) $423-426$. 
[17] Conti M.E., Arias P.M., Descomposición de los rastrojos de soja vs. maíz. Influencia sobre las formas húmicas del suelo, in: XVI Cong. Arg. Ciencia del Suelo, Villa Carlos Paz, 1998, pp. 41-42.

[18] Cordone G.E., Ostojic J.J., Ferrari M.C., DE Gonzalez G.C., Los residuos de la cosecha de soja, maíz y girasol: cantidad, calidad y distribución en la superficie del suelo. Campaña 1990/91, INTA, Carpeta de Producción vegetal EEA Pergamino, Tomo X, Serie Generalidades, Informe 77, 1991.

[19] Cordone G.E., Ferrari M.C., Ostojic J.J., Planas G., Caracterización de los residuos de cosecha de los principales cultivos del norte de la provincia de Buenos Aires, in: XIV Congr. Arg. de la Ciencia del suelo, Mendoza, Argentina, 25-29 October, 1993, pp. 191-192.

[20] Choné T., Andreux F., Correa J.C., Volkoff B., Cerri C.C., Changes, organic matter in an Oxisol from the central Amazonian forest during eight years as pasture, determinated by isotopic composition, in: Berthelin J. (Ed.), Diversity of Environmental Biogeochemistry, Elsevier, Amsterdam, 1991, pp. 397-405.

[21] Dalal R.C., Mayer R.J., Long-term trends in fertility of soils under continuous cultivation and cereal cropping in southern Qeensland. II Total organic carbon and its rate of loss from the soil profile, Aust. J. Soil Res. 24 (1986) 281-292.

[22] Desjardins T., Andreux F., Volkoff B., Cerri C.C., Organic carbon and ${ }^{13} \mathrm{C}$ contents in soils and soil size-fractions, and their changes due to deforestation and pasture installation in eastern Amazonia, Geoderma 61 (1994) 103-118.

[23] Ferrari M.C., Cordone G.E., Ostojic J.J., De Gonzalez G.C., Los residuos de la cosecha: cantidad, calidad y distribución en la superficie del suelo. Campaña 1991/92. INTA, Carpeta de Producción vegetal, EEA Pergamino, Tomo X, Serie Trigo, Informe 137, 1992.

[24] Gregorich E.G., Ellert B.H., Monreal C.M., Turnover of soil organic matter and storage of corn residue carbon estimated from natural ${ }^{13} \mathrm{C}$ abundance, Can. J. Soil Sci. 75 (1995) 161-167.

[25] Guérif J., Modification de la répartition et de l'évolution des matières organiques par la simplification du travail du sol: conséquences sur quelques propriétés physiques, in: INRA ed., Les rotations céréalières intensives. Dix années d'études concertées, INRA-ONICITCF, 1973-1983, 1986, pp. 63-88.

[26] Hauman L., Les modifications de la Flore Argentine sous l'action de la Civilisation (Essai de Géobotanique humaine) Académie Royale de Belgique.
Classe des Sciences. Mémoires. Collection $4^{\circ}$, Deuxième série, Tome IX, fasc. 3, 1928.

[27] Heal O.W., Anderson J.M., Swift M.J., Plant litter quality and decomposition: an historical overview, in: Cadisch G., Giller K.E. (Eds.), Driven by Nature: Plant Litter Quality and Decomposition, CAB International, 1997, pp. 157-174.

[28] Hendrix P.F., Chun-Ru Han, Groffman P.M., Soil respiration in conventional and no-tillage agroecosystems under different winter cover crop rotations, Soil Till. Res. 12 (1988) 135-148.

[29] Instituto Nacional de Tecnologia Agropecuaria (INTA), Carta de suelos de la República Argentina, Hoja 3360-32, Pergamino, Buenos Aires, 1972, 106 p.

[30] Instituto Nacional de Tecnologia Agropecuaria (INTA), Carta de suelos de la República Argentina, Hoja $3360-7$ et 8, Totoras et Serodino, Buenos Aires, $1985,143 \mathrm{p}$.

[31] Jenkinson D.S., Harkness D.D., Vance E.D., Adams D.E., Harrison A.F., Calculating the annual input of organic matter to soil from measurements of total organic carbon and radiocarbon, Soil Biol. Biochem. 24 (1992) 295-308.

[32] Lewis J.P., Collantes M.B., Pire E.F., Carnevale N.J., Bocanelli S.I., Stofella S.L., Prado D., Floristic groups and plant communities of southeastern Santa Fe, Argentina, Vegetatio 60 (1985) 67-90.

[33] Marshall R.B., Whiteway J.N., Automation on a interface between a nitrogen analyzer and isotope ratio mass spectrometer, Analyst 110 (1985) 867-871.

[34] Monnier G., Stengel P., Guérif J., Recherche de critères de la fertilité physique du sol et de son évolution en fonction du système de culture, in: Lanza F. (Ed.), C. R. Séminaire CEE Agrimed, Italy, 1982, pp. 5-52.

[35] Morel R., Chabouis C., Bourgeois S., Evolution des taux d'azote et de carbone organiques dans un sol nu après 15 ans d'enfouisement de pailles sous différentes conditions, Agronomie 1 (1981) 7-17.

[36] Moscatelli G.N., Los suelos de la region pampeana, in: Barsky O. (Ed.), El desarrollo agropecuario pampeano, INDEC-INTA-IICA, Buenos Aires, 1991, pp. 11-76.

[37] Odell R.T., Melsted S.W., Walker W.M., Changes in organic $\mathrm{C}$ and $\mathrm{N}$ of Morrow plot soils under different treatments: 1904-1973, Soil Sci. 137 (1984) $160-171$.

[38] Omay A.B., Rice C.W., Maddux L.D., Gordon W.B., Changes in soil microbial and chemical properties 
under long-term crop rotation and fertilization, Soil Sci. Soc. Am. J. 61 (1997) 1672-1678.

[39] Ostojic J.J., Cordone G.E., Ferrari M.C., Torioni E., Los residuos de la cosecha de soja, maíz y girasol: cantidad, calidad y distribución en la superficie del suelo, Girasol (Campaña 1991/92), INTA, Carpeta de Producción vegetal, EEA Pergamino, Tomo XI, Serie Girasol, Informe 49, 1992.

[40] Paustian K., Parton W.L., Persson J., Modeling soil organic matter in organic-amended and nitrogenfertilized long-term plots, Soil Sci. Soc. Am. J. 56 (1992) 476-488.

[41] Plénet D., Lubet E., Juste C., Evolution à long terme du statut carboné du sol en monoculture non irriguée du maïs (Zea mays L.), Agronomie 13 (1993) 685-698.

[42] Rasmussen P.E., Allmaras R.R., Rohde C.R., Roager N.C. Jr., Crop residue influences on soil carbon and nitrogen in a wheat-fallow system, Soil Sci. Soc. Am. J. 44 (1980) 596-600.

[43] Rasmussen P.E., Collins H.P., Long-term impacts of tillage, fertilizer, and crop residue on soil organic matter in temperate semiarid regions, $\mathrm{Adv}$. Agron. 45 (1991) 93-134.

[44] Rasmussen P.E., Parton W.J., Long-term effects of residue management in wheat-fallow: I. Inputs, yield, and soil organic matter, Soil Sci. Soc. Am. J. 58 (1994) $523-530$.

[45] Tallarico L., Caravello R., El suelo en la región triguera argentina. Programa de trigo y cebada cervecera, IDIA/INTA, 233 (1967) 172-181.

[46] Vanlauwe B., Diels J., Sanginga N., Merckx R., Residue quality and decomposition: an unsteady relationship?, in: Cadisch G., Giller K.E. (Eds.), Driven by Nature: Plant Litter Quality and Decomposition, CAB International, 1997, pp. 157-174.

[47] Van Soest T.J., Wine R.H., Use of detergents in analysis of fibrous feeds. VI. Determination of plant cell constituants, J. Official Analyt. Chem. 50 (1967) 50-55.

[48] Varvel G.E., Rotation and nitrogen fertilization effects on changes in soil carbon and nitrogen, Agron. J. 86 (1994) 319-325. 